Raymond Martineau MD FRCP(C), William H. Noble MD FRCP(C)

\title{
Hypoxaemia created by pulmonary oedema after pulmonary microemboli in dogs
}

Pulmonary microemboli may play a role in the adult respiratory distress syndrome, creating both putmonary oedema and hypoxaemia. We measured the time course of pulmonary oedema and hypoxaemia after pulmonary microemboli of $63-74 \mu$ starch were infused into dogs. Dogs were divided into two groups: six dogs that did not develop pulmonary oedema, and seven that did. Im. mediately after emboli there was no difference between groups in the large fall in $\mathrm{PaO}_{2}$ or the rise in $\dot{Q} s i \dot{Q}$. Therufore the hypoxaemia of pulmonary embolism is not created by pulmonary oedema. As pulmonary oedema increased with time in the oedematous dogs, $\mathrm{PaO}_{2}$ fell further. There was no further reduction in $\mathrm{PaO}_{2}$ in the dogs who did not develop pulmonary oedema. We conclude that hypoxaemia after pulmonary embolism may lie worsened if pulmonasy oedema occurs, but the immediate large reduction in $\mathrm{PaO}_{2}$ after embolism is not created by pulmonary oedema.

\section{Key words}

LUNC: hypoxaemia, pulmonary oedema. EMBOLISM: pulmonary microembolism.
Pulmonary oedema is a clinical finding in the adult respiratory distress syndrome.' When oedema occurs, it causes arterial hypoxaemia due to the increased physiologic shunt and ventilation-perfusion abnormalities. ${ }^{2.3}$ Pulmonary embolism also causes arterial hypoxaemia, most likely secondary to ventilation-perfusion abnormalities, ${ }^{4-6}$ although an increased anatomic shunt through vascular collaterals or the opening of a probe-patent foramen ovale may also occur. $5,7,8$

Because pulmonary oedema may occur following pulmonary embolism ${ }^{7,9,10}$ blood gases cannot readily be used to evaluate the clinical course of pulmonary embolism. The purpose of this experiment was: (a) to study the time course of arterial hypoxaemia following pulmonary embolism, (b) to document the occurrence of pulmonary oedema after pulmonary embolism, and (c) to evaluate the consequences of pulmonary aedema on blood gases when the latter occurs.

Pulmonary oedema was quantitated with an in vivo measurement technique based on the double indicator dilution principle. ${ }^{11-13}$ We used small particles of starch to simulate pulmonary embolism because there are suggestions that ARDS may result from microemboli of fibrin, fat, leukocytes or platelets. $^{14}$

\section{Methods}

Animal preparation and measurements

Fifteen mongrel dogs weighing between 16 and $36 \mathrm{~kg}$ were studied. Anaesthesia was induced with pentobarbital $30 \mathrm{mg} / \mathrm{kg}$, intravenously, and maintained with additional $50 \mathrm{mg}$ bolus injections, as required. The animals breathed room air spontaneously throughout the experiment. Body temperature was monitored.

The femoral artery and pulmonary artery were 
catheterized in order to monitor pressurc continuously. The left atrium was catheterized in a retrograde manner via the carotid artery. ${ }^{15}$ All lines were kept patent by intermittent flushing with saline, which represented the total fluid input. Arterial and mixed venous blood samples were analyzed for blood gases and hacmoglobin concentration; all values were corrected for body temperature, and $\mathrm{O}_{2}$ contents were calculated from this data. Mixed expired gases, simultaneously collected through a tracheostomy, were analysed. Venous admixture and pulmonary dead space were then calculated using standard equations. ${ }^{16}$

Cardiac output and lung water $\left(E T V_{L}\right)$ were measured using the thermodilution double indicator technique as previously described. ${ }^{11-13}$ Pulmonary vascular resistance ${ }^{16}$ and pulmonary microvascular pressure were derived using Gaar's formula (Pmv $=\mathrm{P}_{\mathrm{LA}}+0.4\left(\mathrm{P}_{\mathrm{PA}}-\mathrm{P}_{\left.\mathrm{LA}_{\mathrm{A}}\right)}{ }^{17}\right.$ No heparin was used throughout the experiment.

Blood samples taken at the beginning and end of the experiments were analyzed for total proteins, and colloid asmotic pressure (COP) was calculated. $^{18}$

\section{Protocol}

After control measurements, starch microemboli $63-74 \mu$ in diameter were infused to create a significant rise in $\mathbf{P}_{\mathbf{P A}}$. The starch was injected through a large bore catheter inserted into the external jugular vein as a single bolus or as multiple boli given within a period of ten minutes. The total dose varied between 0.1 and $0.3 \mathrm{gm} / \mathrm{kg}$.

Immediately after embolization, measurements were taken. The results of these measurements will be identified as "immediate." Thereafter, measurements were made every 30 minutes over a period of four hours. The last measurement obtained at the end of the period will be identified as "late." Three animals died spontaneously before the end of the period, and in these cases the last measurement prior to death was used.

At the end of the experiment, the animals were killed with an intravenous dose of $\mathrm{KCl}$, and the lungs excised. The extravascular lung water was determined using a gravimetric method to measure pulmonary extravascular tissue weight (PETW). ${ }^{12}$

Statistical analysis of the results was carried out using a two-way analysis of variance. The analysis was continued using Dunnett's and Tukey's tests

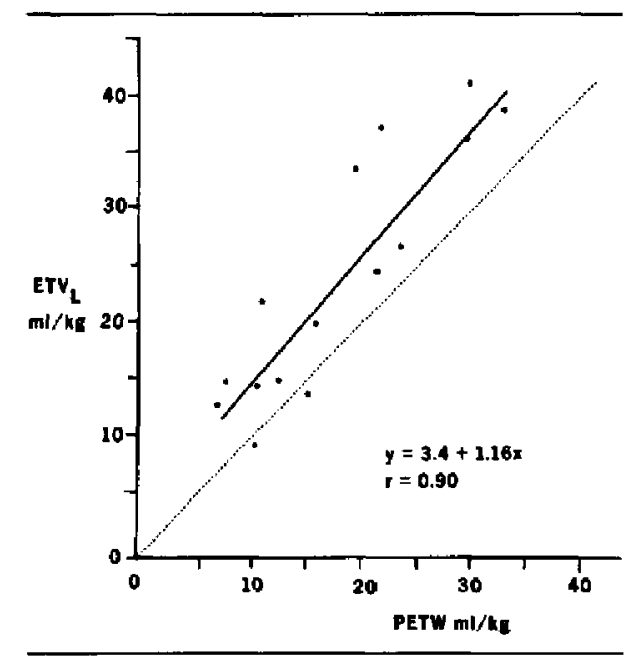

FIGURE 1 Correlation between in vivo measuremenc of lung water (ETV $)$ and the post-mortem gravimetric method (PETW).

for multiple comparisons between the means. Comparisons between groups were made using Student's $t$ test for paired and unpaired values. "P" less than 0.05 was considered significant. ${ }^{19}$ Only significant changes will be discussed. Data are reported as mean $\pm S E M$.

\section{Results}

As shown in Figure 1, there is a good correlation between the in vivo measurement of lung water $\left(E T V_{L}\right)$ and the post mortem lung water measurement (PETW) $(r=0.90)$.

Two animals did not survive embolization because of cardiovascular collapse. They both had a single bolus of emboli of $0.2 \mathrm{gm} / \mathrm{kg}$. Both survived for five minutes after the emboli so that lung water measurements were obtained. Neither dog developed oedema, with normal values for PETW and ETV $_{L}$ obtained. The two lowest PETW data points in Figure 1 are from these dogs. The closeness of these two data points to the regression line indicates that even in these dying dogs ETV $L$ has accurately quantitated lung water immediately after embolization of the lungs. Aside from this comparison of ETV $\mathrm{L}_{\mathrm{L}}$ and PETW these dogs have been excluded from the results.

In order to determine the consequences of pulmonary oedema on blood gases, animals were 
arbitrarily divided into two groups according to the results of PETW: those having less than $16 \mathrm{ml} / \mathrm{kg}$ of body weight forming the "no pulmonary oedema" group; those having more than $16 \mathrm{ml} / \mathrm{kg}$ forming the "pulmonary oedema" group. The "no pulmonary oedema" group included six dogs and the "pulmonary oedema" group seven dogs. The amount of starch administered was not significantly different between these groups.

The venous admixture rose and the arterial $\mathrm{PO}_{2}$ dropped markedly $(p<0.005$ ) in both groups immediately after embolization and was not different between groups. The "pulmonary oedema" group had a further drop in arterial $\mathrm{PO}_{2}$ in the late perici which was statistically significant ( $p<$ 0.025 ), while there was no further significant change in the "no pulmonary oedema" group. In the "no pulmonary oedema" group there was a slight rise in the mean lung water value at the end of the experiment. In the "pulmonary oedema" group there was a small, but significant, increase in pulmonary oedema immediately after embolization $(p<0.05)$, and a marked increase by the end of the experiment $(\mathrm{p}<0.001$ ). In three dogs, gross frothy oederna was seen in the tracheo-bronchial tree at the end of the experiment, and they died before the end of the four-hour period. There was a marked rise in the mean pulmonary artery pressure immediately after embolization for both groups of animals ( $p<$ 0.005 ). The increase in mean pulmonary artery pressure immediately after embolization was greater in the "pulmonary oedema" group than in the "no pulmonary oedema" group. (Fig. 2)

The arterial $\mathrm{pH}, \mathrm{PCO}_{2}$ and pulmonary dead space are reported in Table $I$. As expected, there was a marked increase in pulmonary dead space caused by embolization. The arterial $\mathrm{PCO}_{2}$ dropped in both groups during the experiment, which explains the small rise in arterial $\mathrm{pH}$. There were no statistical differences between the two groups for any of these parameters.

The haemodynamic values are shown in Table II. Cardiac output dropped toward the end of the experiment in the "pulmonary oedema" group, however the drop was not significantly different from that of the "no pulmonary oedema" group.

The mean pulmonary vascular resistance and the mean pulmonary micro vascular pressures rose markedly in both groups immediately after embolization. However, comparisons between the two
TABLE I Gas exchange results

\begin{tabular}{|c|c|c|c|c|}
\hline & & Control & Immediate & Late \\
\hline pH & $\begin{array}{l}\text { P.E. } \\
\text { N.P.E. }\end{array}$ & $\begin{array}{l}7.34 \pm 0.02 \\
7.37 \pm 0.02\end{array}$ & $\begin{array}{l}7.32 \pm 0.02 \\
7.36 \pm 0.02\end{array}$ & $\begin{array}{l}7.42 \pm 0.03^{* \dagger} \\
7.45 \pm 0.01^{* \dagger}\end{array}$ \\
\hline $\begin{array}{l}\mathrm{PCO}_{2} \\
\mathrm{kPa} \text { (torr) }\end{array}$ & $\begin{array}{l}\text { P.E. } \\
\text { N.P.E }\end{array}$ & $\begin{array}{r}5.39 \pm 0.28 \\
(40.5 \pm 2.1) \\
5.53 \pm 0.13 \\
(41.6 \pm 1.0)\end{array}$ & $\begin{array}{c}5.17 \pm 0.37 \\
(38.9 \pm 2.8) \\
5.51 \pm 0.25 \\
(41.4 \pm 1.9)\end{array}$ & $\begin{aligned} 3.42 & \pm 0.25^{*}+ \\
(25.7 & \pm 1.9) \\
3.51 & \pm 0.19 * \dagger \\
(26.4 & \pm 1.4)\end{aligned}$ \\
\hline $\begin{array}{l}V_{\mathrm{D}} / \mathrm{V}_{\mathrm{T}} \\
\%\end{array}$ & $\begin{array}{l}\text { P.E. } \\
\text { N.P.E. }\end{array}$ & $\begin{array}{l}50.1 \pm 3.5 \\
51.8 \pm 4.7\end{array}$ & $\begin{array}{l}74.9 \pm 5.1^{*} \\
75.9 \pm 6.6^{*}\end{array}$ & $\begin{array}{l}75.4 \pm 3.7^{*} \\
70.9 \pm 4.8^{*}\end{array}$ \\
\hline
\end{tabular}

P.E. - Pulmonary oedema group; N.P.E. - No pulmonary oedema group; $V_{\mathrm{D}} / \mathrm{V}_{\mathrm{T}}$ - Pulmonary dead space.

"Significant difference when compared to "control."

+Significant difference when compared to "immediate."

groups is not statistically valid since left atrial pressure could only be monitored in four of the six animals with no pulmonary oedema.

COP of blood was not significantly different from the beginning to the end of experiments, or between groups $(16.6 \pm 0.2 \mathrm{~mm} \mathrm{Hg}, 2.21 \pm 0.03 \mathrm{kPa})$.

\section{Discussion}

Our in vivo measurement of lung water using the double indicator dilution principle has been previously described and was shown to be reliable in canine haemorrhagic shock ${ }^{20}$ and hypervolemic oedema. ${ }^{21}$ In this experiment, we have shown that this technique is also reliable to quantitate pulmonary oedema in a micro emboli model (Figure 1). The extrayascular thermal volume of the lung $\left(E_{T} V_{L}\right)$ was higher than the post-mortem extravascular tissue weight (PETW). This is attributed to the heat exchange which occurred with the bronchiolar tree, the left heart, and the pulmonary artery and veins. ${ }^{12}$ Neither sequestration of blood behind occluded pulmonary capillaries nor the restricted pulmonary capillary bed appeared to interfere with the measurement of lung water since the ratio of $\mathrm{ETV}_{\mathrm{L}} /$ PETW in this experiment $(1.41 \pm 0.01)$ was not significantly different from that ratio in volume overload oedema experiments $(1.55 \pm 0.17) .{ }^{13} \mathrm{By}$ allowing serial measurements of lung water, this in vivo technique not only has the advantage of determining when pulmonary oedema occurs but also quantifies its formation rate.

The haemodynamic response of animals to embolization was highly variable. Some dogs were able to sustain large amounts of starch micro emboli 
TABLE II Haemodynamic results

\begin{tabular}{|c|c|c|c|c|}
\hline & & Control & Immediate & Late \\
\hline $\begin{array}{l}\text { C.O. } \\
(1 / \min )\end{array}$ & $\begin{array}{l}\text { P.E. } \\
\text { N.P.E. }\end{array}$ & $\begin{array}{l}3.51 \pm 0.32 \\
2.98 \pm 0.33\end{array}$ & $\begin{array}{l}2.66 \pm 0.34^{*} \\
3.04 \pm 0.42\end{array}$ & $\begin{array}{l}2.03 \pm 0.21^{*} \\
2.33 \pm 0.34\end{array}$ \\
\hline $\begin{array}{l}P_{\text {LA }} \\
k P_{a} \text { (torr) }\end{array}$ & $\begin{array}{l}\text { P.E. } \\
\text { N.P.E. }\end{array}$ & $\begin{array}{r}0.61 \pm 0.09 \\
(4.6 \pm 0.7) \\
0.88 \pm 0.31 \\
(6.6 \pm 2.3)\end{array}$ & $\begin{array}{c}0.61 \pm 0.12 \\
(4.6 \pm 0.9) \\
0.59 \pm 0.23 \\
(4.4 \pm 1.7)\end{array}$ & $\begin{array}{c}0.45 \pm 0.13 \\
(3.4 \pm 1.0) \\
0.99 \pm 0.25 \\
(7.4 \pm 1.9)\end{array}$ \\
\hline $\begin{array}{l}\mathrm{P}_{\overline{\mathrm{PA}}} \\
\mathbf{k P a} \text { (torr) }\end{array}$ & $\begin{array}{l}\text { P.E. } \\
\text { N.P.E. }\end{array}$ & $\begin{aligned} 2.33 & \pm 0.08 \\
(17.5 & \pm 0.6) \\
2.61 & \pm 0.19 \\
(19.6 & \pm 1.4)\end{aligned}$ & $\begin{array}{c}6.25 \pm 0.43^{*} \\
(46.9 \pm 3.2) \\
5.03 \pm 0.40^{*} \\
\left(37.7 \pm 3.0^{\circ}\right)\end{array}$ & $\begin{aligned} 5.6 & \pm 0.36 * \\
(42.0 & \pm 2.7) \\
4.69 & \pm 0.39 * \\
(35.2 & \pm 2.9)\end{aligned}$ \\
\hline $\begin{array}{l}\mathrm{PVR} \\
\mathrm{dyn} / \mathrm{sec} / \\
\mathrm{cm}^{5}\end{array}$ & N.P.E. & $310 \pm 4.4$ & $\begin{array}{l}1490 \pm 348 * \\
1106 \pm 403\end{array}$ & $\begin{array}{l}1710 \pm 367^{*} \\
1306 \pm 494\end{array}$ \\
\hline $\begin{array}{l}P_{m v} \\
\mathbf{k P a} \text { (tor) }\end{array}$ & $\begin{array}{l}\text { P.E. } \\
\text { N.P.E. }\end{array}$ & $\begin{array}{r}1.31 \pm 0.05 \\
(9.8 \pm 0.4) \\
1.65 \pm 0.23 \\
(12.4 \pm 1.7)\end{array}$ & $\begin{array}{c}2.87 \pm 0.23^{*} \\
(21.5 \pm 1.7) \\
2.43 \pm 0.16 \\
(18.2 \pm 1.2)\end{array}$ & $\begin{array}{c}2.51 \pm 0.16^{*} \\
(18.8 \pm 1.2) \\
2.52 \pm 0.15 \\
(19.0 \pm 1.1)\end{array}$ \\
\hline
\end{tabular}

*Significant difference when compared to control.

C. O. - cardiac output; $\mathrm{P}_{\mathrm{LA}}-$ left atrial pressure (mean); $\mathrm{P}_{\overline{\mathrm{PA}}}-$ pulmonary artery pressure (mean); PVR - pulmonary vascular resistance; $P_{m v}$ - pulmonary micro vascular pressure; $P$.E. pulmonary oedema/N.P.E. - no pulmonary oedema.

while others required only a minimal dose to raise their pulmonary artery pressure. This variability has been noted by others. ${ }^{5}$ The mechanical obstruction imposed on the pulmonary circulation by the micro emboli explains the pulmonary hypertension. Reflex vasoconstriction mediated by the endogenous release of vasoactive substances augments the pulmonary hypertension and may explain the variability seen in the haemodynamic response. ${ }^{22}$

Based on an arbitrarily chosen value for the post mortem measurement of lung oedema $(16 \mathrm{ml} / \mathrm{kg})$ and in order to examine the effects of oedema on gas exchange we divided the animals into two groups. This division corresponded to a final increase in ETV $_{L}$ of 51 per cent of pre-embolization control values in the "no pulmonary oedema" group as opposed to 147 per cent in the "pulmonary oedema" group. A previous study has shown the anatomical correlation of pulmonary oedema with the magnitude of increase of ETV ${ }_{L}{ }^{23}$ A rise of less than 60 per cent of the baseline value comelated with early interstitial ocdema, while a rise of more than $85 \mathrm{per}$ cent was associated with alveolar oedema. Therefore, in the present study, the "no pulmonary oedema" group may also have some animals with early pulmonary oedema. However, interference in pulmonary gas exchange by early interstitial oedema is less likely to be of clinical significance. ${ }^{23}$ On the other hand, pulmonary alveolar oedema interferes markedly with pulmonary gas exchange and causes severe arterial hypoxaemia. ${ }^{23}$ The rise in lung water seen immediately after pulmonary embolization in the "pulmonary oedema" group is not likely to cause significant impairment in gas exchange since it represented an increase of only 41 per cent of control value. The fact that there is alveolar oedema in one group and interstitial oedema in the other group at the late stage and yet a very small mean difference in $\mathrm{PaO}_{2}$ is support for the concept that oedema is not creating the major part of hypoxaemia after embolism. These findings, along with the fact that $\mathrm{PaO}_{2}$ fell to the same degree immediately after embolization (whether there was interstitial oedema present, or not (Figure 2)), allows us to conclude that hypoxaemia immediately after pulmonary embolism is not created by pulmonary oedema. Our results show an immediate drop in arterial $\mathrm{PO}_{2}$ following embolization which was assucialed with an immediate rise in venous admixture, while the mean pulmonary artery pressure increased. Several mechanisms may explain the hypoxaemia seen following pulmonary embolism. ${ }^{4-6}$ Ventilation-perfusion abnormality is likely the most important mechanism, because of the redistribution of pulmonary circulation to areas that are hypoventilated 24-26 $^{26}$ possibly not ventilated at all. ${ }^{26,27}$

When pulmonary oedema did occur, arterial hypoxaemia worsened. In the no pulmonary oedema group, arterial $\mathrm{PO}_{2}$ did not worsen. In addition to the uneven distribution of blood flow caused by embolization, it is likely that uneven distribution of ventilation caused by alveolar oedema created more physiological shunt and ventilation-perfusion abnormalities, and therefore pulmonary gas exchange was further impaired. ${ }^{3}{ }^{7}$ The reduced cardiac output we found would also enhance the effect of these shunts and further reduce $\mathrm{PaO}_{2}$.

The mechanism of pulmonary oedema formation following pulmonary micro embolism is still controversial. ${ }^{7}$ However, it has recently been shown that two types of pulmonary oedema can occur following embolization; a no permeability type, similar to high pressure oedema was seen when 


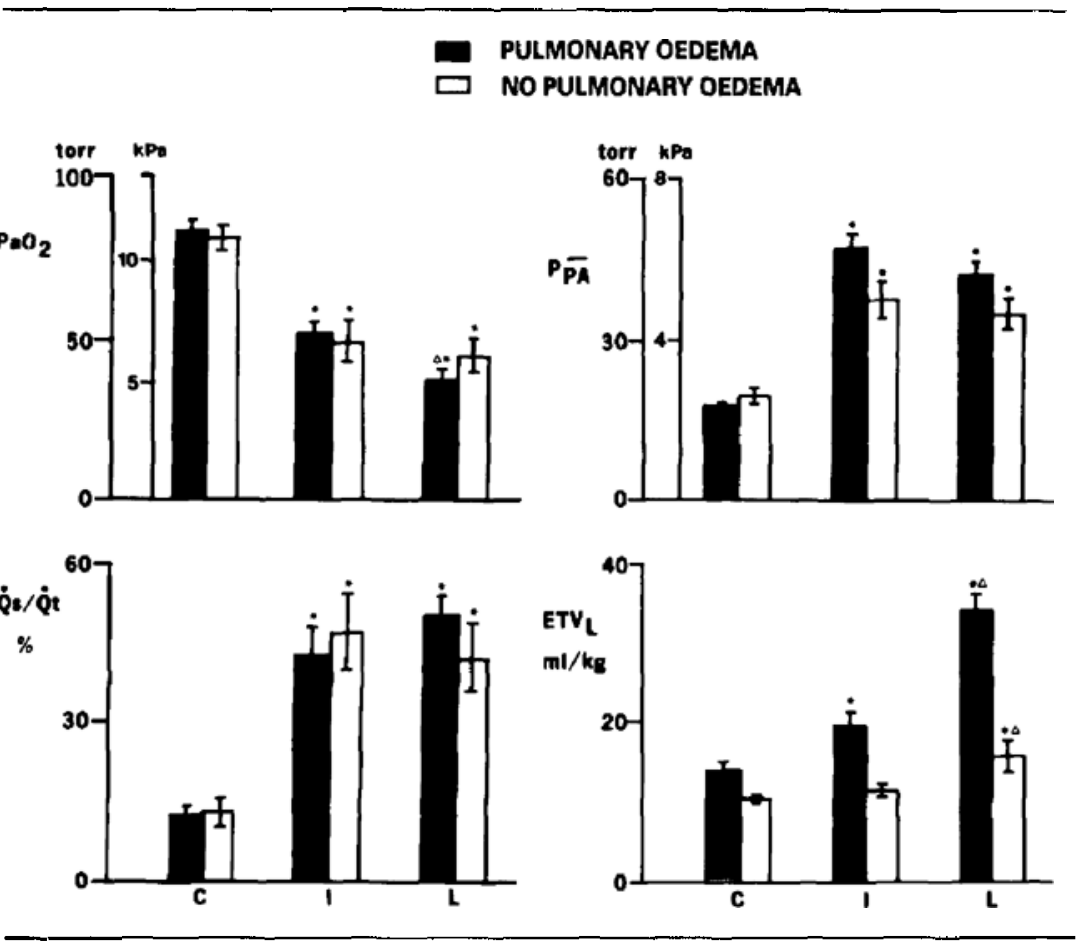

FIGURE 2 Comparison of the results for the pulmonary oedema group and the "no pulmonary oederna" group. C - control period; I - immediately after embolization; $L$ - late (at the end of the expcriment); $\bar{Q}_{s} \dot{Q}_{1}$ - venous admix ture; $\mathrm{P}_{\overline{\mathrm{PK}}}$ - mean pulmonary artery pressure; $E T V_{L}$ - extravascular thermal volume of the lung; ${ }^{*}$ - significant difference when compared to "control"; $\Delta$ - significant difference when compared to "immediate."

large-sized beads were used, and a permeability type of oedema was induced by smaller-sized glass beads. ${ }^{28}$ In our study the size of starch micro emboli used would have been small enough to induce pulmonary capillary damage in addition to the high micro vascular pressure.

In septic pigs Lava et al. ${ }^{29}$ found pulmonary oedema was a function of the magnitude of pulmonary artery pressure. In our study there was a significantly greater increase in mean pulmonary antery pressure in the pulmonary oedema group with a high degree of variability. This suggests that the pulmonary hypertension worsened the pulmonary oedema but is not conclusive. The variability of pulmonary artery pressure response with similar embolic mechanical obstruction suggests vasoactive substances have been released and these sub- stances may play a role in increasing pulmonary capillary permeability. Regardless of whether the pulmonary oedema is created by pulmonary artery hypertension or increased pulmonary capillary permeability, Starling's equation ${ }^{30}$ and current literature $^{31-34}$ suggest one of the therapeutic goals should be to reduce pulmonary micro vascular pressure.

\section{Acknowledgements}

We are grateful to P. Slusarenko, E. Hobbs, G. Caskennette and J.C. Kay for providing expert technical assistance, typing, and editing. 


\section{References}

1 Nobie WH. Pulmonary oedema: a review. Can Anaesth Soc J 1980; 27: 286-302.

2 West JB. Pulmonary physiology - the essentials. Chapter 8: Respiratory failure. The Williams \& Wilkins Company (1977).

3 Wagner PD, Laravuso RB, Goldzimmer E, Naumann $P F$, West JB. Distributions of vertilation perfusion ratios in dogs with normal and abnormal lungs. J Appl Physiol 1975; 38: 1099-1109.

4 Rosenow EC, Osmundson PJ, Brown ML. Pulmonary embolism. Mayo Clin Proc 1981; 56: 161-8.

5 Kovacs GS, Hill JD, Alberg $T$ et al. Pathogenesis of arterial hypoxemia in pulmonary embolism. Arch Surg 1966; 93: 813-8.

6 Levy SE, Simmons DH. Mechanism of arterial hypoxaemia following pulmonary thromboembolism in dogs. J Appl Physiol 1975; 39: 41-6.

7 Alfery $D D$, Benumof $J L$. Anaesthesia for uncommon diseases. Chapter: Pulmonary Disease. Edited by Katz, J., Benumof, J.L., \& Kadis, L.B. W.B. Saunders Co. (1981).

8 Byrick RJ, Kolton $M$, Hart JT, Forbath, PG. Hypoxemia following cardiopulmonary bypass. Anesthesiology 1980; 53: 172-4.

9 Hyers TM, Fowler AA, Wicks AB. Focal pulmonary edema after massive pulmonary embolism. Am Rev Respir Dis 1981; 123: 232.

10 Garvey JW, Wisoff G, Voletti C, Hartstein $M$. Hemorrhagic pulmonary edema: post-pulmonary embolectomy. Thorax 1976; 31: 605-10.

1] Noble WH, Severinghaus $J W$. Thermal and conductivity dilution curves for rapid quantitation of pulmonary oederta. J Appl Physiol 1972; 32: $770-5$.

12 Noble WH, Obdrzalek J, Kay JC. A new technique for measuring pulmonary oedema. J Appl Physiol 1973; 34: 508-12.

13 Noble WH, Kay JC, Maret KH, Caskanette G. Reappraisal of extravascular lung thermal volume as a measure of pulmonary oedema. J Appl Physiol 1980; 48: 120-9.

14 Saldeen $T$. The microembolism syndrome. Micro Res 1976; 11: 227-59.

15 Noble WH, Kay JC. Cardiac catheterization in dogs. Can Anaesth Soc J 1974; 21; 616-20.

16 Nunn JF. Applied Respiratory Physiology Edition I, London, 1969, Butterworth \& Co. Ltd. pp. $191,220,244,263$.
17 Gaar KA Jr, Taylor AE, Owens LJ, Guyron AC. Pulmonary capillary pressure and filtration coefficient in the isolated perfused lung. Am J Physiol 1967; 213: 910-5.

18 Landis EM, Pappinheimer JR. Exchange of substances through the capillary walls. Handbook of Physiology, Section 2, 2: 974.

19 Snedecor GW, Cochrane WG. Statistical Methods, 6th Edition, Iowa State University Press, Iowa City (1967).

20 Noble WH. Early changes in lung water after hemorrhagic shock in pigs and dogs. Can Anaesth Soc J 1975; 22: 39-46.

21 Noble WH, Kay JC, Obdrzalek J. Lung mechanics in hypervolemic pulmonary edema. $\mathrm{J}$ Appl Physiol 1975; 38: 681-7.

22 Stein $M$, Levy SE. Reflex and humoral responses to pulmonary embolism. Prog Card Dis 1974; 17: $167-74$.

23 Noble WH, Kovacs $K_{,}$Kay JC. Fine structural changes in haemodynamic pulmonary edema. Can Anaesth Soc J 21: 1974; 275-84.

24 Dantzker DR, Wagner PD, Torabene VW, Alazrake NP, West JB. Gas exchange after pulmonary thromboembolisation in dogs. Circ Res 1978 ; 42: 92-103.

25 Fisher J, Noble WH, Kay JC. Hypoxaemia following pulmonary embolism: A dog model of altering regional perfusion. Anesthesiology 1981; 54: 204-9.

26 Kadiri $Y Z, K a y, J C_{1}$ Kovacs $K$, Noble WH. Pulmonary embolism distribution to ventilated and unventilated lungs in the dog: a cause of hypoxaemia. Can Anaesth Soc J 1980; 27: 216-22.

27 Benumof $J L$, Wahrenbrock EA. Blunted hypoxic pulmonary vasoconstriction by increased vascular pressures. J Appl Physiol 1975; 38: 846-51.

28 Johnson A, Malik AB. Effects of different-size micro-emboli on lung fluid and protein exchange. J Appl Physiol 1981; 51: 461-70.

29 Lava JS, Rice CL, Levine HA, Moss GS. Extravascular lung water as a function of the magnitude of pulmonary artery pressure in the septic pig. J Surg Res 1982; 32: 440-8.

30 Starling $E H$. On the absorption of fluids from the connective tissue spaces. J Physiol London 1896; 19: 312-8.

31 Staub NC. Pathogenesis of pulmonary edema. Prog Card Dis 1980; 23: 53-70.

32 Byrick RJ, Finlayson DC. Noble WH. Pul- 
monary arterial pressure increases during cardiopulmonary bypass: a potential cause of pulmonary edema. Anesthesiology 1977; 46: 433-40.

33 .Zapol WM, Snider MT. Pulmonary hypertension in severe acute respiratory failure. N.E.J.M. 1977; 296: 476-81.

34 Prewith RM, McCarthy J, Wood LDH. Treatment of acute low pressure pulmonary edema in dogs. $\mathrm{J}$ Clin Invest $1981 ; 67: 409-15$.

Résumé

Les microembolies pulmonaires peuvent jouer un rôle important dans le syndrome d'insuffisance respiratoire des adultes en creant a la fois l'adème pulmonaire et l'hypaxémie. Nous avons mesuré l'effer de l'action de l'adème pulmonaire et de l'hypoxémie après que des chiens furent injectés avec des microembolies d'amidon (63-73 $\mu)$. Les chiens étaient divisés en deux groupes: un des ces groupes était composé de sept chiens qui développèrent l'ademe pulmonaire et l'autre de six chiens qui ne le developpèrent pas. Immédiatement après l'injection des embolies, on ne trouva pas de différence entre les devox groupes par rapport da la chute importante du $\mathrm{PaO}_{2}$ ou par rapport à la hausse du $\dot{Q} s i \dot{Q} t$. Par conséquent, l'hypoxémie de l'embolisme pulmonaire ne résulte pas de l'adème pulmonaire. A mesure que les adèmes pulnonaires augmenterent avec le temps chez les chiens adémateux, le $\mathrm{PaO}_{2}$ chuta plus bas. Il n'y eut plus de réduction dans $\mathrm{le}_{\mathrm{PaO}}$ chez les chiens qui n'avaient pas développé d' ademe pulmonaire. Nous concluons que l'hypoxémie après emboiisme pulmonaire peut être empirée s'il y a adème pulmonaire, mais la réduction imméidiate du $\mathrm{PaO}_{2}$ après l'embolisme ne résulte pas de l'adème pulmonaire.

\section{Addendum}

Re: Leighton $K M$, Lim SL, Wilson $N$. Arginine vasopressin response to anaesthesia produced by halothane, enflurane and isoflurane. Can Anaesth Soc J Vol 29, November 1982. Pages 563-566.

The following acknowledgement was omitted in the original printing of this article:

"The research reported was supported by a Grantin-Aid of Research awarded by the British Columbia Heart Foundation."

\section{Erratum}

Re: Moffitt EA, Sethna DH, Gray RJ, Raymond MJ, Matloff JM, Bussell JA. Nitrous oxide added to halothane reduces coronary flow and myocardial oxygen consumption in patients with coronary disease. Can Anaesth Soc J Vol 30, January 1983. Pages 5-9.

Gray RJ was inadvertently spelled Gary. 